Michał Kwaśniewski

(Międzyrzecz)

\title{
Kobieta przedsiębiorcza - moja praprababka Katarzyna Gummert w świetle aktu notarialnego z 1893 r.
}

Wśród zachowanych pamiątek przeszłości w domowych archiwach rodzin pochodzenia chłopskiego trudno odnaleźć dokumenty, które ze względu na swój czas powstania, treść bądź walory artystyczne stanowiłyby interesujący materiał badawczy, nie tylko dla osoby mającej do nich stosunek emocjonalny, ale także dla badacza historii społeczności regionu czy kraju. Dlatego nawet najczęściej występujące, z pozoru nieciekawe, będące wytworem urzędniczego, wojskowego czy sądowego szablonu dokumenty, w połączeniu z dokładną analizą porównawczą sytuacji życiowej, materialnej i zawodowej danej osoby, potrafią przybliżyć nie tylko fakty z życia jednostki, ale również ukazać ciekawy obraz panujących realiów.

Przetrwaniu dokumentów w chłopskich gospodarstwach nie sprzyjał fakt częstych pożarów drewnianych domostw oraz złe warunki przechowywania. Na stan i liczebność dokumentów miały także wpływ zdarzenia losowe, takie jak np. działania wojenne czy klęski żywiołowe. Należy też wspomnieć o specyficznym stosunku ludności wiejskiej do odziedziczonych po przodkach dokumentów, które niejednokrotnie po wielu latach, w ramach "porządków”, trafiały po prostu do kaflowego pieca.

Dzieje analizowanego w tym opracowaniu dokumentu doskonale wpisują się w omówione powyżej uwarunkowania stanu zachowania rodzinnych archiwów ludności wiejskiej w Polsce. Pod koniec II wojny światowej, prawdopodobnie w lutym 1945 r., radzieckie wojska wysiedliły na kilka miesięcy zamieszkałą we wsi Głażewo rodzinę Franciszki Kropp (1906-1993) z domu Gummert. Według przekazów rodzinnych, pomimo umieszczenia sztabu 1. Frontu Białoruskiego na Lipowcu w Międzychodzie, marszałek Gieorgij Żukow na swą kwaterę wybrał położony w Głażewie, w odległości ok. ośmiu 
km od Międzychodu, obszerny dom Kroppów-Gummertów. Ten znajdujący się na lekkim wzniesieniu na skraju wsi murowany budynek powstał w 1901 r. z inicjatywy syna mojej praprababki - Franciszka Gummerta (1873-1944). Radzieccy sołdaci, organizując kwaterę marszałka Żukowa, wyrzucili cały dobytek rodziny Kroppów-Gummertów do budynków inwentarskich. Przyczyniło się to do utraty wielu rodzinnych dokumentów, mebli i obrazów. Między innymi uległ zniszczeniu jedyny wizerunek mojej praprababki Katarzyny Gummert i jej męża Michała, którzy - choć przesłonięci - są częściowo widoczni na zdjęciu z uroczystości weselnych Franciszki Gummert i Hieronima Kroppa z 1936 r. (Fot. 1.). Jedną z kilku ocalałych rodzinnych pamiątek był akt notarialny umowy sprzedaży nieruchomości gruntowej położonej w Głażewie, pochodzący z 1893 r., który stał się przedmiotem analizy w niniejszym opracowaniu. $\mathrm{W}$ ramach tej pracy została także dokonana transliteracja pisma gotyckiego na pismo łacińskie oraz przepisano tekst polskiego tłumaczenia niemieckiego pierwowzoru analizowanego aktu notarialnego (Zał. 1.).

Tekst aktu notarialnego został sporządzony przez notariusza Jakuba Urbacha w Międzyrzeczu 10 maja 1893 r. Jako kupująca nieruchomość występuje moja praprababka Katarzyna Gummert (1842-1922) z domu Mizgajska, wdowa po Michale Gummercie (1838-1892), a jako sprzedający zostali wymienieni kupcy: Oskar Hoese z Lipowca ${ }^{1}$ pod Międzychodem oraz Juliusz Lesser z Cottbus ${ }^{2}$.

Przechowywany $\mathrm{w}$ rodzinnym archiwum, a omawiany $\mathrm{w}$ niniejszym opracowaniu akt notarialny z 1893 r., jest poświadczonym przez notariusza odpisem oryginalnego dokumentu, wydanym dla Katarzyny Gummert jako jednej ze stron umowy sprzedaży nieruchomości gruntowej. Pomimo że sporządzony i poświadczony przez notariusza odpis ma wartość oryginału, celem próby porównania kopii z oryginałem przeprowadzona została kwerenda w Archiwum Państwowym w Gorzowie Wlkp. W zasobach tegoż archiwum, $w$ ramach zespołu ${ }^{3}$ pod nazwą "Akta notariusza Jacob Urbach z Międzyrzecza" przechowywane są trzy jednostki archiwalne zawierające uporządkowane akty notarialne sporządzone przez międzyrzeckiego notariusza Jakuba Urbacha. Notariusz ten wykonywał swój zawód w Międzyrzeczu na pewno w latach 1890-1895, co można wywnioskować po skrajnych datach zachowanych dokumentów. Akty notarialne pochodzące kolejno z lat: 1890, 1891 i 1895, zostały zarchiwizowane w osobnych poszytach w ramach danego rocznika. Niestety, nie zachował się poszyt m.in. dla roku 1893, dlatego niemożliwa stała się próba porównania odpisu przechowywanego w rodzinnym

\footnotetext{
${ }^{1}$ Lipowiec (Lindenstadt) - wieś, która w 1905 r. została włączona do miasta Międzychód.

${ }^{2}$ Cottbus (Chociebuż) - miasto nad Sprewą, we wschodnich Niemczech.

${ }^{3}$ Zespół nr 206, sygn. 1 - 1890 r., sygn. 2 - 1891 r., sygn. 3 - 1895 r.
} 


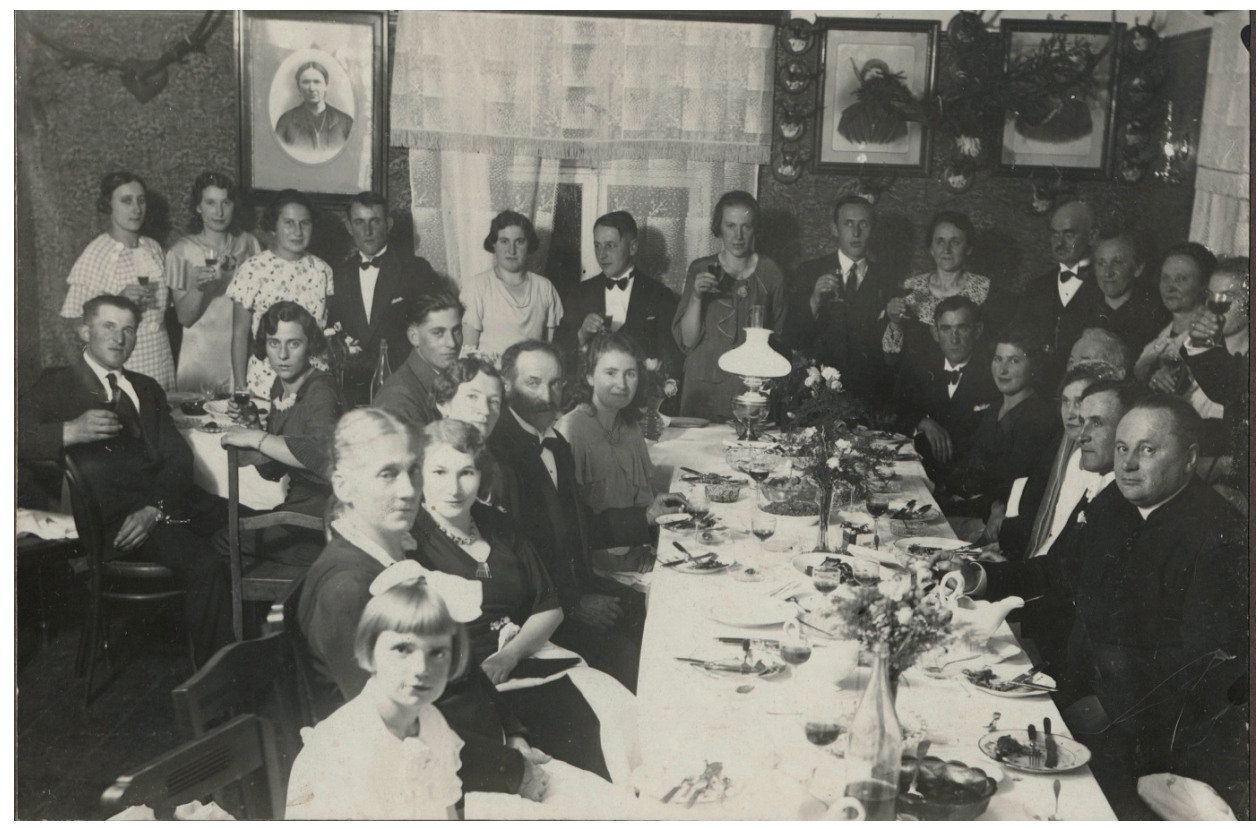

Fot. 1. Wesele Franciszki Gummert (1906-1993) i Hieronima Kroppa (1906-1949), wnętrze domu w Głażewie w 1936 r.

Źródło: kopia zdjęcia ze zbiorów Witolda Kroppa z Głażewa.

archiwum z oryginałem. Ponadto pierwopis aktu notarialnego był jedynym znanym dokumentem, na którym widniał własnoręczny podpis Katarzyny Gummert. Pomimo braku próbki pisma mojej praprababki, sam fakt podpisu pod aktem notarialnym może świadczyć, że dzięki otrzymanemu podstawowemu wykształceniu umiała ona czytać i pisać. Trzeba zaznaczyć, że zmiany w szkolnictwie $\mathrm{w}$ zaborze pruskim z początkiem lat czterdziestych XIX w., czyli w czasach, gdy moja praprababka uczęszczała do szkoły elementarnej, polegały na odrodzeniu polskiej szkoły ludowej w Wielkim Księstwie Poznańskim ${ }^{4}$, co związane było ze wzrostem skolaryzacji i zaufania polskiej ludności do niemieckiego szkolnictwa. Działania te były ściśle związane z wstąpieniem na tron Prus Fryderyka Wilhelma IV ${ }^{5}$ i zapoczątkowaną przez niego odwilżą w stosunkach z polską ludnością.

Akt notarialny został sporządzony w języku niemieckim i na wyraźne żądanie Katarzyny Gummert przełożony także na język polski przez tłumacza i sekretarza sądowego Johanna Schwarza z Międzyrzecza. Zapewne było to podyktowane bardziej pragmatycznym podejściem do sprawy mojej prapra-

\footnotetext{
4 S.I. Możdżeń, Historia wychowania 1795-1918, Sandomierz 2008, s. 191-193.

${ }^{5}$ Fryderyk Wilhelm IV - król Prus w latach 1840-1861.
} 
babki niż względami związanymi z chęcią zamanifestowania polskoścí. Być może poziom znajomości języka niemieckiego był niewystarczający, by zrozumieć, a później należycie wypełniać treść zawartej umowy. Przedmiotem sprzedaży stała się nieruchomość gruntowa o powierzchni ok. 17 ha i 25 arów, położona w obrębie wsi Głażewo, będąca własnością wyżej wymienionych Hoesego i Lessera. Granice działki podlegającej sprzedaży zostały określone w oparciu o dwie drogi - do Dormowa i Dormowa Młyn, oraz granice działek Marianny Borowiak, Franciszka Kurka i Franciszka Genzmera.

Cena sprzedaży osiągnęła wartość 12 tys. mk niemieckich, czyli w przeliczeniu na jeden ha ziemi wyniosła $695,65 \mathrm{mk}$. Była to dobra cena i zgodna z wyliczoną średnią $(694,1 \mathrm{mk})^{7}$ dla wszystkich trzech klas ${ }^{8}$ ziemi w Prowincji Poznańskiej dla lat 1890-1894. W ramach zadatku moja praprababka uiściła dziesięć proc. od ceny sprzedaży gruntu. Ze względu na wielkość kwoty Katarzyna Gummert uzgodniła ze sprzedającymi podział wierzytelności na raty, które zobowiązała się spłacić w ciągu sześciu lat, do 7 maja 1899 r. W Archiwum Państwowym w Gorzowie Wlkp. nie przetrwały żadne dokumenty - takie jak księgi hipoteczne ${ }^{9}$, które potwierdzałby spłatę pozostałej kwoty i przejęcie działki gruntu na własność. Przechowywany w domowym archiwum akt notarialny z 17 października 1935 r., wystawiony dla Franciszka Gummerta i jego córek - Franciszki i Anieli, w lakoniczny sposób w par. szóstym określa: „,Strony są zgodne w tem, że hipoteki zapisane na wyżej wymienionych nieruchomościach ${ }^{10}$ są spłacone oraz w tem, że wymiernica Katarzyna Gummert umarła oraz, że renta jest spłacona". Niestety, nie jest możliwe ustalenie, jakim areałem $\mathrm{w}$ chwili zakupu nieruchomości dysponowała moja praprababka w $1893 \mathrm{r}$.

Koniecznie w ramach niniejszego opracowania należy przybliżyć - na ile jest to możliwe - sylwetkę mojej praprababki oraz wydarzeń z życia jej najbliższych, które miały miejsce na krótko przed zawarciem omawianego aktu notarialnego. Tylko w ten sposób można zrozumieć trudną sytuację życiową, w jakiej znalazła się Katarzyna Gummert, i wyobrazić sobie wyzwanie, jakie

${ }^{6}$ Wśród przechowywanych w AP Gorzów Wlkp. aktów notarialnych sporządzonych przez Jacoba Urbacha pod sygn.. 3, na stronach 100-105 mamy do czynienia również z aktem sporządzonym w dwóch językach, także dla zamieszkałej w Głażewie Zuzanny Świderek $\mathrm{z}$ domu Kaczmarek.

7 T. von Jackowski, Der Bauernbesitz in der Provinz Posen im 19. Jahrhundert, Lipsk 1914, s. $127-128$.

${ }^{8}$ Jackowski dzieli ziemie na lekkie (leichter Boden), średnie (mittlerer Boden) i ciężkie (schwerer Boden). Kolejno dla wymienionych klas wyznacza cenę za jednego ha ziemi w latach 1890-1894: 631,8 mk; 706,5 mk; 712,9 mk.

${ }^{9} \mathrm{Z}$ powodu pożaru archiwum sądu w Międzyrzeczu pod koniec II wojny światowej dla wsi Głażewo w ramach zespołu archiwalnego Sąd Obwodowy w Międzychodzie zachowało się tylko sześć jednostek archiwalnych - ksiąg hipotecznych, pod sygn. 2524-2529.

10 Głażewo karta 44, 77, 29, 97 i Łowyń karta 227. 
powzięła w 1893 r., zobowiązując się do spłaty ponad dziesięciu tys. mk niemieckich za zakupioną ziemię.

Katarzyna Gummert urodziła się 11 listopada 1842 r. w Głażewie ${ }^{11}$ koło Międzychodu jako córka Walentego Mizgajskiego (ok. 1815-1892), rolnika z Głażewa, i Julianny Marianny Jesionek (1817-1893). Ochrzczona została 13 listopada 1842 r. w kościele parafialnym w Kamionnie. Rodzina jej ojca wywodziła się ze starej, zasiedziałej rodziny Mizgajów, o której pierwsze informacje w księgach metrykalnych parafii w Kamionnie pojawiają się w $1711 \mathrm{r}$. Przodkowie Katarzyny Gummert w początkach XVIII w. mieszkali na kmiecym gospodarstwie w Głażewie, następnie w wyniku ślubu prapradziadka Katarzyny przenieśli się do Dormowa Młyn, by po kilkudziesięciu latach powrócić do Głażewa. Od początków XIX w. nazwisko Mizgaj zostało „uszlachcone" poprzez dodanie do nazwiska przyrostka -ski. Katarzyna Mizgajska nie miała łatwego życia, 14 lutego 1865 r. urodziła córkę Anastazję, pochodzącą z nieprawego łoża, skazując się $\mathrm{w}$ ten sposób na ludzki ostracyzm. Pomimo tego piętna 7 lutego 1866 r. Katarzyna Mizgajska wyszła za mąż, w swoim kościele parafialnym w Kamionnie, za pochodzącego ze Stoków koło Pszczewa Michała Gummerta, syna Andrzeja Gummerta (1799-1886), karczmarza w Stokach, i Julianny Kolan (1813-1865). Świadkami tego wydarzenia byli m.in. zapisani w metryce ślubu Jan Vogel i Maciej Gummert, brat pana młodego.

W związku z Michałem Gummertem Katarzyna urodziła w Głażewie dziesięcioro dzieci:

1. Martę, ur. 19 lutego 1867 r., zamężną Lubik;

2. Albertynę, ur. 11 kwietnia 1869 r., zamężną Paech;

3. Walentego, ur. 6 lutego 1871 r.;

4. Andrzeja, ur. 18 listopada 1872 r.;

5. Franciszka Ksawerego, ur. 21 listopada 1873 r.;

6. Mariannę Józefę, ur. 21 marca 1876 r., zamężną Pade;

7. Antoninę, ur. 7 grudnia 1878 r., zamężną Fiedler;

8. Stanisława Feliksa, ur. 28 kwietnia 1881 r.;

9. Błażeja Jana, ur. 18 czerwca 1885 r.;

10. Feliksa Antoniego, ur. 18 maja 1887 r.

Dwoje z nich zmarło w wieku niemowlęcym, tj.: Walenty (zm. 10 stycznia 1872 r.) oraz Stanisław (zm. 15 listopada 1881 r.). Natomiast Andrzej zmarł zaraz po porodzie. tj. 18 listopada 1872 r. Pozostali potomkowie Michała i Katarzyny Gummertów, poza synem Błażejem, założyli własne rodziny.

${ }^{11}$ Wówczas miejscowości leżącej w powiecie międzyrzeckim (Kreis Meseritz), w autonomicznym Wielkim Księstwie Poznańskim (Großherzogtum Posen) wchodzącym w skład Królestwa Prus (Königreich Preußen). 
W ciągu dziesięciu miesięcy Katarzyna Gummert straciła najpierw ojca 17 marca 1892 r., następnie męża - 4 sierpnia tego samego roku, i w końcu matkę - 13 stycznia 1893 r. Miała pięćdziesiąt lat, była wdową z ośmiorgiem dzieci, przy czym najmłodsze z nich miało zaledwie pięć lat. Trudno wyobrazić sobie gorszą sytuację życiową - w jednym czasie odeszli wszyscy jej najbliżsi, pozostało kilkudziesięciohektarowe gospodarstwo do obrobienia, córki na wydaniu oraz kilkoro małych dzieci do wyżywienia i wykształcenia. Mimo to, a być może właśnie z tego powodu i w wyniku otrzymania spadku po mężu Katarzyna Gummert zdobyła się na nielada wyczyn - powiększyła swoje gospodarstwo rolne za sumę dwunastu tys. mk niemieckich, co potwierdza omówiony $\mathrm{w}$ niniejszym opracowaniu akt notarialny. Na pewno niełatwo było spłacić taką kwotę, która równała się np. blisko dwunastoletniej pensji miejskiego nauczyciela pod koniec XIX w. Z cytowanego już wcześniej aktu notarialnego z 1935 r. wiadomo na pewno, że przedsięwzięcie Katarzyny z 1893 r., polegające na kupnie ponad siedemnastohektarowej nieruchomości rolnej, odniosło sukces.

\section{Załącznik nr 1. Akt notarialny kupna nieruchomości gruntowej położonej w Głażewie przez Katarzynę Gummert w 1893 roku}

\section{[s. 1]}

No 123 des Notariats=Register für das Jahr 1893.

Ein Stempelbogen über Einhundert Mark ist vorgehabtes

\section{Verhandelt}

zu Meseritz und zehnten Mai Ein= tausend achthundert drei und neunzig. Vor dem unterschriebenen in Meseritz wohnhaften Notar im Bezirke des Königlichen Oberlandesge= richts zu Posen,

Jacob Urbach

welchem, wie er versichert, keines der Verhältnisse entgegensteht, welche nach den Paragraphen fünf und sechs des Gesetzes vom elften Juli Achtzehnhundert fünf und vier= zig von der Theilnahme an die= ser

[s. 2]

ser Verhandlung ausschließen, er= schienen heute persönlich bekannt und verfügungsfäsig (?):

1. der Kaufmann Oskar Hoese wohnhaft zu Lindenstadt bei Birnbaum;
Działo się

w Międzyrzeczu, dnia dziesiątego

Maja tysiąc ósm set dziewięćdziesiątego

trzeciego roku.

Przed podpisanym w Międzyrzeczu zamieszkałym

notariuszem w obwodzie sądu Królewskiego nadziemiańskiego w Poznaniu

Jakobem Urbach,

któremu, jak on zapewnia, żaden

z stosunków nie stoi na przeszkodzie,

które go podług paragrafów piątego

i szóstego prawa $z$ dnia jedena-

stego lipca roku tysiąc ośm set

czterydziestego piątego od udziału przy

czynności niniejszej wykluczają, sta-

wili się dziś z osoby znani i w

stanie prawodzielnym:

1. Kupiec Oscar Hoese zamieszkały w Lindenstadt pod Międzychodem; 
2. der Kaufmann Julius Lesser wohnhaft zu Cottbus;

3. die verwittwete Frau Eigen= thümer Catharina Gummert ge= borene Mizgajski wohnhaft zu Glozewo.

Catharina Gummert ist vollkom= men nur der polnischen Sprache mächtig, weshalb auf ihren Antrag der gerichtlich vereidete, dem $\mathrm{No}=$ tar persönlich bekannte in Meseritz wohnhafte Dolmetscher der polnischen Sprache, Herr Gerichtssecretär Johann Schwarz zugezogen wurde, welchem, wie hiermit versichert wird

\section{[s. 3]}

wird, keines der gesetzlichen

Hindernisse entgegensteht, die ihn nach den Paragraphen sieben bis neun und neun und zwanzig des Gesetzes vom elften Juli achtzehnhundert fünfundvierzig von der Theilnahme an dieser Verhand= lung ausschließen würden. Dolmetscher die Willensmein= nung der Catharina Gummert, die der anderen unmittelbar, wo= bei sich folgendes ergab: die Erschienen schließen fol= genden Kaufvertrag.

\section{Paragraph eins}

Oskar Hoese und Julius Lesser verkaufen von ihrem Grund= stück Glozewo vierzehn eine Ackerparzelle im Flächenin halt

\section{[s. 4]}

halt von ungefähr siebzehn Hectaren und fünfundzwan= zig Aren, begrenzt von dem nach Dormowo führenden Wege dem nach den Dormowo er Mühlen führenden Wege und den Besitzungen der Marianna Bartkowiak, Franz Kurek und Franz Genzmer, in Pausch und Bogen, wie Alles steht und liegt, an Catha= rina Gummert
2. Kupiec Juliusz Lesser zamieszkały w Kotbusie;

3. owdowiała właścicielka Katarzyna Gummert z domu Mizgajska zamieszkała w Głożewie.

Katarzyna Gummert dokładnie li tylko polskim włada językiem, zatem na jej żądanie został przywołany sądownie przysięgą zobowiązany, notaryuszowi osobiście znany w Międzyrzeczu zamieszkały tłumacz języka polskiego, sekretarz sądowy pan Jan Schwarz, któremu, co się niniejszem zapewnia, żadna z

z prawych przeszkód, które go by podług paragrafów siódmego aż do dziewiątego i dwudziestego dziewiątego prawa $\mathrm{z}$ dnia jedenastego lipca tysiąc ośm set czterydziestego piątego roku od udziału przy czynności niniejszej wykluczyć mogły, na przeszkodzie nie stoją.

Notaryusz wybadał przez tłómacza wolę Katarzyny Gummert, wolę zaś innych bezpośrednio, przyczem się wykazało, co następuje: Stawający zawierają następujący kontrakt kupna.

paragraf pierwszy

Oskar Hoese i Juliusz Lesser sprzedają od swego gruntu pod numerem czternastym w Glożewie położonym jedną parcelę

ziemi w rozmiarze około siedemnaście hektarów i dwadzieścia i pięć arów wynoszącą - graniczącą przy drodze ku Dormowie prowadzącej, przy drodze do dormowskich młynów prowadzącej i przy własnościach Marianny Bartkowiak, Franciszka Kurka i Franciszka Genzmer położonej ryczałtem, jak wszystko stoi i leży, Katarzynie Gummert na własność. 
Paragraph zwei

der Kaufpreis beträgt zwölf= tausend Mark darauf sind Eintau= send zweihundert Mark bereits bezahlt, Verkäufer quittieren darüber.

Neunhundert Mark werden am ersten Juli dieses Jahres gezahlt, vom siebenten dieses Monats $\mathrm{ab}$ mit fünf Prozent verzinst der

\section{[s. 5]}

der Restbetrag mit Neuntau= send neunhundert Mark wird am siebenten Mai des Jahres Eintausendachthundert neun und neuzig gezahlt und vom siebenten dieses $\mathrm{Mo}=$ nats ab mit fünf Prozent in halbjährigen Terminen ver= zinst, auch bei der Auflassung in Grundbuche sowohl erwor= benen Parzelle als auch des sanstigen aus dem Nachlasse des Ehemannes der Käuferin herrührenden Grundbesitzer unter Hypothekenbriefbil= dung eingetragen, der $\mathrm{Hy}=$ pothekenbrief den Gläubi= gern zu Händen des Oskar Hoese übersandt. Capital und Zinsen werden frei am jedes maligen Wohnorte der Gläu=

\section{[s. 6]}

Gläubiger solange derselbe im deutschen Reiche belegen ist und zwar an jeden zur Hälfte gezahlt.

Paragraph drei die Stebergabe ist bereits er= folgt. Gefahren und Nutzungen sind seit siebenten dieses Monats auf die Käuferin übergenagen. Abgaben und Lasten einschlie $\beta=$ lich der Aktheilung zwei ein= getragenen Rentenpflicht über= nimmt die Käuferin vom ersten Juli dieses Jahres ab insoweit als dieselben von der paragraf drugi

Cena kupna wynosi dwanaście tysięcy marek. Na to są już

zapłacone jeden tysiąc dwieście marek, z czego sprzedający kwitują.

Dziewięć set marek zostaną zapłacone na dniu pierwszego lipca tego roku, a od siódmego tego miesiąca po pięć od sta aprowizowane.

Reszta w ilości dziewięć tysięcy dziewięć set marek zostanie zapłacona na dniu siódmego maja roku tysiąc ośm set dziewięćdziesiątego dziewiątego, a od siódmego tego miesiąca po pięć od sta zaprowizaną $\mathrm{w}$ połrocznych terminach, i przy sądowem spuszczeniu w księdze nieruchomości nabytej parceli jako też na innej ze spadku po mężu kupującej pochodzącej nieruchomości zaintabulowaną pod udzieleniem listu hipotecznego wierzycielom na ręce Oskara Hoese nadesłać się mającego.

Kapitał i procenta mają być płacone wolna na każdorazowem pobyciu mieszkania wierzycieli tak

tak długo dopóki jest położonem $\mathrm{w}$ państwie niemieckim i to każdemu do połowy.

Paragraf trzeci

Tradycya już nastąpiła. Niebezpieczeństwo i użytki przeszły już z siódmym tego miesiąca na rzecz kupującej. Podatki i [ciężary włącznie w oddziale drugim zapisany obowiązek renty przyjmuje kupująca od dnia pierwszego lipca roku bieżącego, o ile takowe przez administracyjną na odprzedaną parcelę podzielone 
zuständigen Verwaltungs= Behrze auf die erkaufte Par= zelle werden vertheilt wer= den.

Mit den Eintragungen Abthei= lung zwei Nummer eis und

\section{[s. 7]}

und zwei ist die Käuferin bekannt, verlangt deren Löschung nicht dagegen ver pflichten die Verkäufer sich alle übrigen Posten der zwei= ten und dritten Abtheilung innerhalb zwei Jahren auf ihre Kosten zur Löschung zu bringen.

Paragraph vier die Auflassung hat jederzeit zu erfolgen, sobald die Verkäufer es bestimmen, spätestens aber bis zweiten October dieses Jahres.

Paragraph fünf die Kosten und Stempel die= ser Vertrages, der Auflassung der Eintragung des Rest= kaufgeldes, der Zeichnung und Karten trägt die Käu fe

s. 8]

ferin

Beantragt wird, derselben eine Ausfertigung zu er= theilen.

diese Verhandlung ist den Erschienenen in Gegenwart des Notares Deutschkund durch den Delmetscher auch pol= laut vorgelesen, von ihnen genehmigt und, wie folgt, eigenhändig unter= schrieben worden.

Oscar Hoese

Julius Lesser

Katarzyna Gummert

Johann Schwarz

Dolmetscher zostaną.

Z intabulowaniami $\mathrm{w}$ dziale drugim pod numerem pierwszym i

i drugim została kupująca oznajmioną i nie żąda ich wymazać. Obowiązują się zaś sprzedający wszystkie inne pozycye drugiego i trzeciego oddziału w przeciągu dwuch lat na własne koszta ku wymazaniu doprowadzić.

\section{Paragraf czwarty}

Sądowe spuszczenie ma każdego czasu nastąpić, skoro to sprzedający ustanowią, najpóźniej zaś aż do drugiego października roku bieżącego.

Paragraf piąty

Koszta i stępel kontraktu niniejszego, spuszczenia sądowego, zaintabulowania, reszty ceny Kupna, rysunku i karty ponosi $\mathrm{Ku}-$ pująca.

Wnosi się o udzielenie wygotowania onegoż.

Czynność niniejsza została stawającym $\mathrm{w}$ przytomności notaryusza $\mathrm{w}$ niemieckim języku i przez tłumacza też w polskim języku głośno przeczytana, przez nich przyjęta i jak następuje, własnoręcznie podpisana.

Oscar Hoese

Julius Lesser

Katarzyna Gummert

Jan Schwarz

tłómacz 
Ich bescheinige hierdurch, daß verstehende Ver= handlung, so wie sie niedergescheiben ist, unter Zuziehung des Gerichtssecretär Johann

\section{[s. 9]}

Johann Schwarz wohnhaft hierselbst

als Dolmetschers der polnischen Sprache

stattgefunden hat, daß sie in meiner

Gegenwart den Erschienenen deutsch

und durch den Dolmetscher auch polnisch

laut vorgelesen, von ihnen genehmigt

und von ihnen sowie dem Dolmet=

scher, wie versteht, eigenhändig unter=

schrieben worden ist.

Jacob Urbach

Verstehende in das Register unter Num= mer einhundertdreiundzwanzig

Jahre eintausendschthundertdreiund

neuzig eingetragene Verhand= lung wird hiermit für die ver=

wittwete Frau Eigenthümer Catha=

rina Gummert geborene Mizgajski

wohnhaft zu Glozewo ausgefer

tigt.

So geschehen zu Meseritz am zehn

ten

\section{[s. 10]}

ten Mai eintausendachthundertdrei

und neunzig.

Jacob Urbach

Notar im Bezirke der Königlichen

Oberlandesgerichts zu Posen.

Rechnung

Gegenstand 1200 Mark

1. Gebühr § 6 u 20 G. u T. v. 11/10 Mai 1851

23,00

2. Polnische Verhandlung

3. Dolmetschergebühren

4. Stempelauslage

120,00

5. Schreibgebühr 


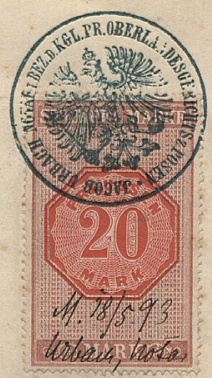

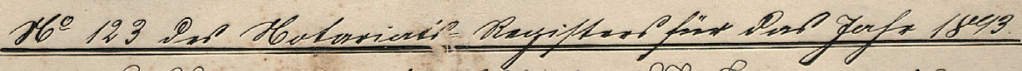

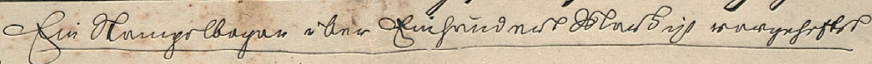

Alfounters Priats ory

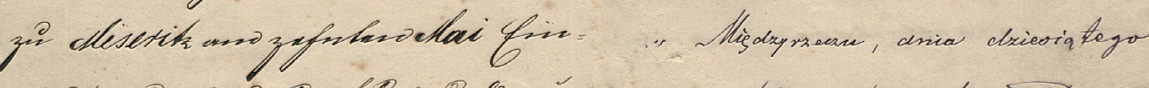

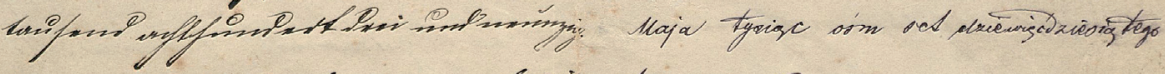

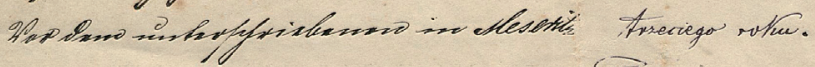

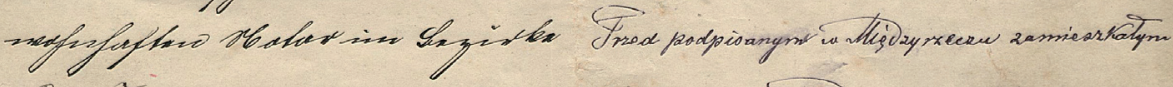

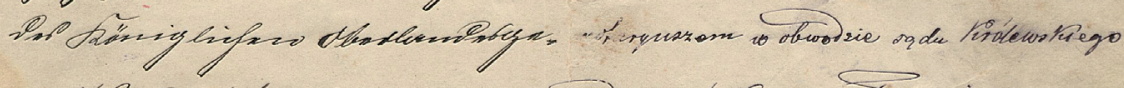
xighty: getwen.

gucab gethache

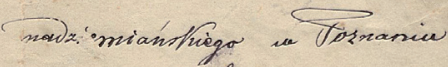

fatiokem Ulikark

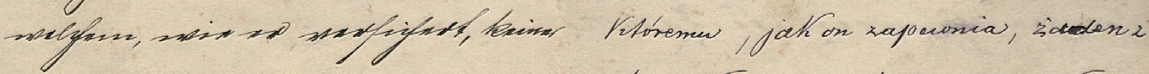

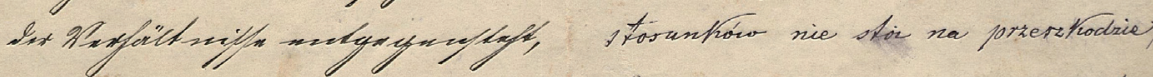

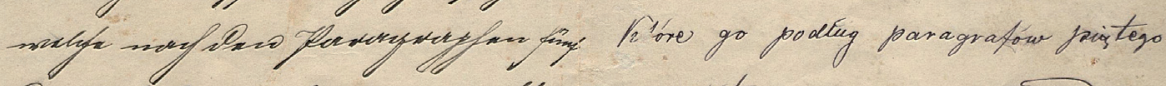

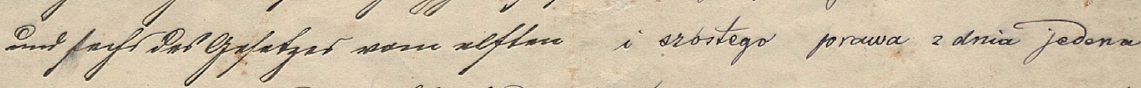

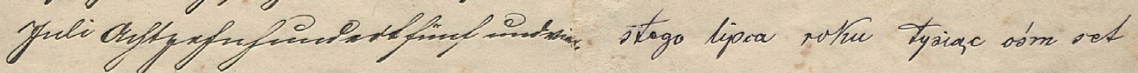

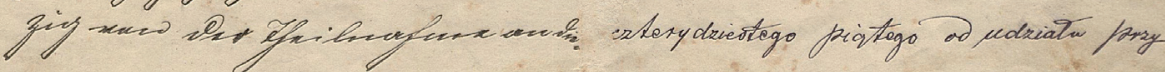
Yos 


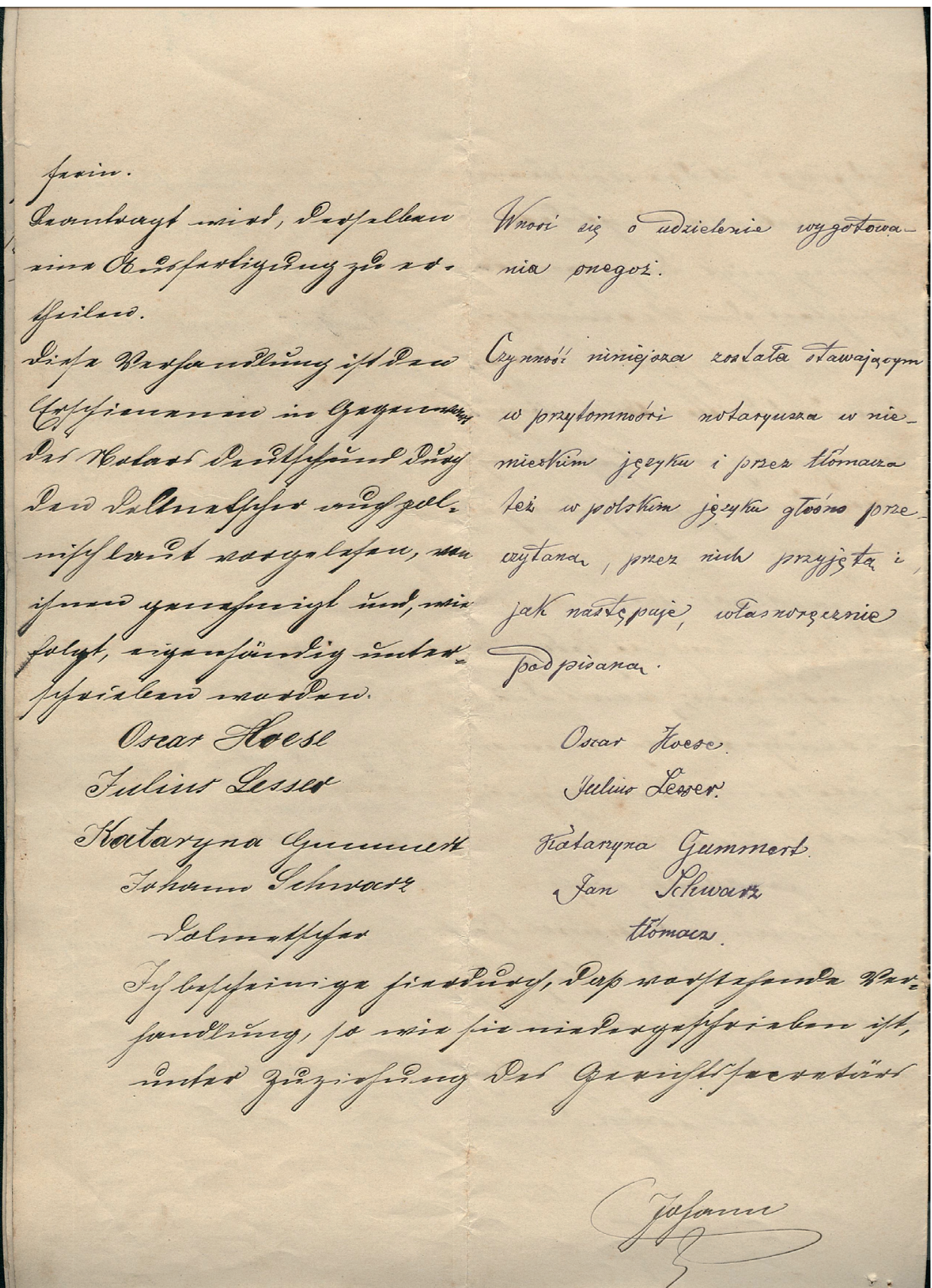




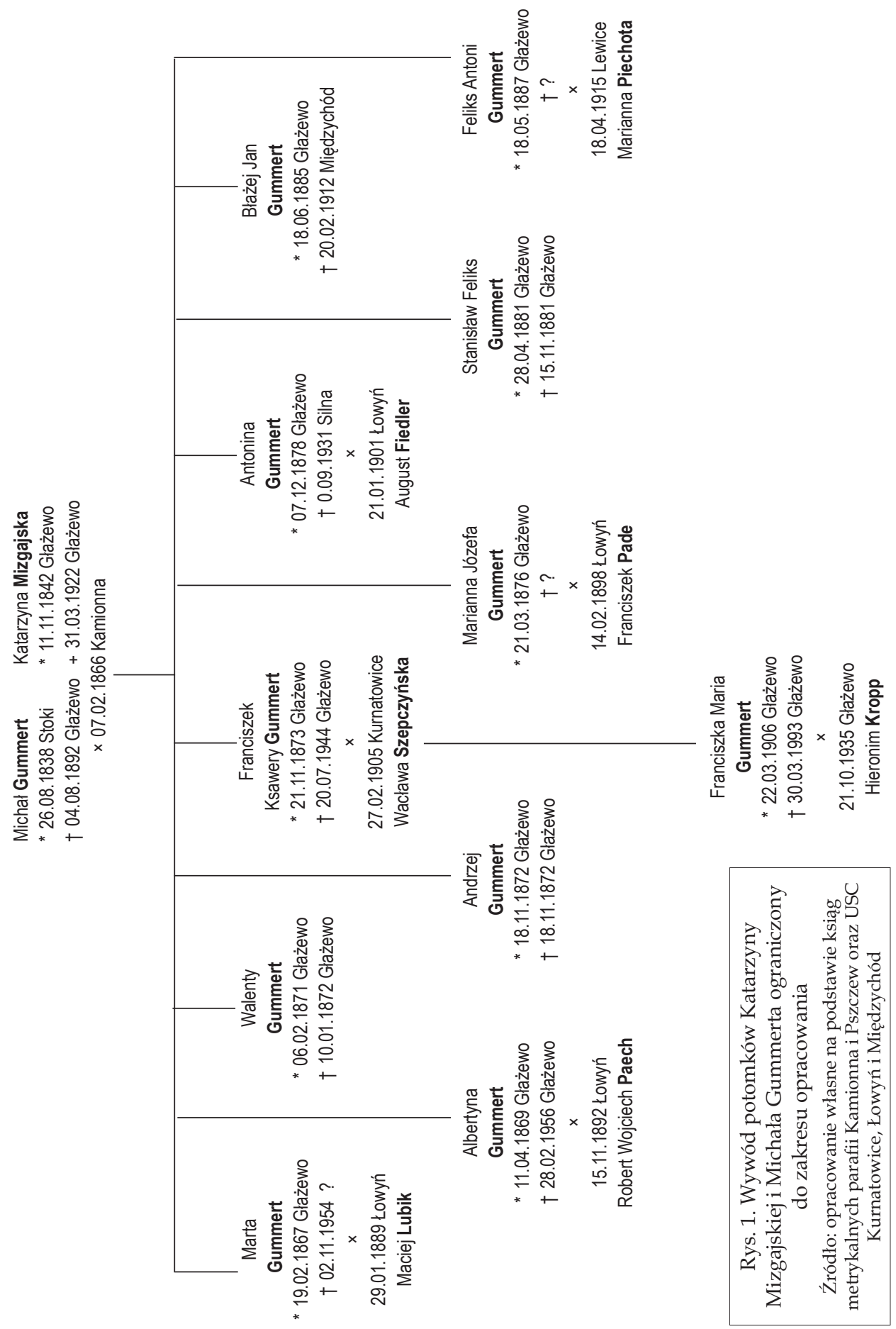


Michał Kwaśniewski

\title{
Kobieta przedsiębiorcza - Katarzyna Gummert w świetle aktu notarialnego z 1893 roku
}

\section{Streszczenie}

Zachowany w archiwum rodzinnym akt notarialny z 1893 r., stał się podstawą do szczegółowego opisu życia praprababci autora. Jednakże nie poprzestaje on tylko wyłącznie na informacji o losach swojej operatywnej przodkini, ale prezentuje także dzieje rodziny chłopskiej oraz ich genealogię.

\section{An entrepreneurial woman - Katarzyna Gummert in the light of a notarial act from the year 1893}

\begin{abstract}
A notarial act from the year 1893 kept in the family archive was the starting point for a detailed description of the life of the author's great-great-grandmother. However, the author not only provides information on the life of his resourceful ancestor, but also presents the history of the peasant family and its genealogy.
\end{abstract}

